\title{
Аналіз харчування осіб, які займаються аквафітнесом
}

\author{
Я. В. Першегуба, Л. Ф. Оксамитна, \\ А. В. Грек
}

Національний університет фізичного виховання і спорту України, Київ, Україна

\begin{abstract}
Резюме. Проведена оценка фактического питания женщин 25-35 лет, которые занимаются аквааэробикой. Показано, что по качественному составу отмечается чрезмерное потребление белков и жиров животного происхождения, моно- , дисахаридов и недостаточное - сложных углеводов при наличии недостаточной мотивации к правильному пищевому поведению. Социально-просветительский тренинг формирования положительной мотивации к правильному пищевому поведению лиц и коррекция суточного пищевого рациона привели к нормализации индекса массы тела у женщин в возрасте 25-35 лет, которые занимаются аквафитнесом.
\end{abstract}

Ключевые слова: суточный пищевой рацион, индекс массы тела, аквафитнес.

Summary. Real nutrition of females aged 25-35 years, who are engaged in aqua aerobics has been evaluated. According to qualitative composition an excessive uptake of proteins and animal fats, mono-disaccharides has been revealed along with insufficient intake of complex carbohydrates in the face of insufficient motivation to proper nutrition behaviour. Socio-educational training of positive motivation formation to proper nutrition and correction of daily dietary intake have resulted in normalization of body mass index in 25-35 years old females engaged in aqua fitness.

Key words: daily dietary intake, body mass index, aqua fitness.

Постановка проблеми. Моніторингові дослідження харчування населення показали, що жінки частіше за чоловіків набирають зайву масу тіла. Для її зниження вони починають «катувати» себе різними низькокалорійними дієтами і голодуванням. Нині користуються популярністю, особливо у жінок, заняття, що поєднують традиційні та нетрадиційні засоби в спортивному залі й на воді [1]. Особливої популярності серед жінок 3 надмірною масою тіла набув новий вид аеробіки - аквааеробіка (аквафрітнес).

Аквааеробіка - це один із різновидів аеробіки, тренування з якої проходять у водному середовищі. На сьогодні це найефективніший засіб для тих, хто хоче відновити здоров'я, схуднути і підтримувати себе в тонусі [2, 5, 6]. Різні комплекси і вправи, адаптовані до води, дозволяють не тільки досягти доброї фрізичної форми, й знайти емоційну стабільність, підвищити рівень працездатності, знизити ризик розвитку різних захворювань.

Аквааеробіка дає можливість займатися людям 3 надмірною масою тіла і $з$ захворюваннями та травмами опорно-рухового апарату. Виштовхувальна сила води знижує масу тіла на $90 \%$. При виконанні стрибкових і бігових рухів вода пом'якшує удари, яким піддаються суглоби.
Стан, що нагадує невагомість, відсутність ударного і осьового навантаження розвантажує суглоби і хребет, знижує ризик отримання травм. У той же час робота, яка спрямована на подолання опору води, сприяє поліпшенню м'язового тонусу. Сила виштовхування допомагає при виконанні вправ для людей з обмеженою рухливістю суглобів. Вправи на гнучкість ніколи не приведуть до пошкодження зв'язок і м'язів, оскільки опір води стримує швидкість рухів і не дозволяє перейти межу індивідуальної амплітуди руху. Це важливо для літніх, фрізично ослаблених, страждаючих ожирінням людей, при остеохондрозі та інших захворюваннях хребта [7].

Плавання саме по собі, навіть у повільному темпі, допомагає «спалити» 200 кал за 30 хв. Виконання різних вправ, які можна згрупувати поняттям аквааеробіка, $\epsilon$ набагато ефрективнішим, ніж виконання тих самих вправ на суші. Вода щільніше повітря у 800 разів, тому тим, хто займається аквааеробікою, доводиться прикладати більше зусиль i, таким чином, витрачати більше енергії, щоб рухатися у воді. Біг у воді, наприклад, спалює 11,5 кал за 1 хв, а на суші -8.

Щоб займатися аквааеробікою, абсолютно необов'язково вміти плавати, оскільки вправи 
виконуються у підтримувальному аквапоясі. Для стимуляції м'язів рук, ніг, живота використовуються спеціальне акваобладнання. Цим заняття аквааеробікою і відрізняються від звичайного плавання в басейні. Ії арсенал рухів більший, а інтенсивність тренування можна вільно варіювати $[10,12]$.

Дослідження виконано згідно зі Зведеним планом НДР у сорері фрізичної культури і спорту на 2011-1915 рр. за темою 3.11 «Розробка системи оздоровчого харчування для осіб, які займаються фрітнесом» (номер держреєстрації 0111U001736).

Мета дослідження - оцінити фрактичне харчування жінок 25-35 років, які займаються аквааеробікою, та розробити рекомендації з його корекції з урахуванням мотивації до здорового харчування.

Методи і організація дослідження. Використано метод теоретичного аналізу, який оснований на узагальненні, синтезі, екстраполяції і аналізі наукової, науково-методичної літератури та інших джерел [4], метод оцінки стану статусу харчування (його класифрікація) за індексом маси тіла (IMT) з визначенням фактора рухової активності (коефіцієнт рухової активності) за інтенсивністю та тривалістю фрізичних навантажень за спеціальною шкалою [8].

Оцінювання фрактичного харчування, індексу маси тіла (IMT), ступеня позитивної мотивації до правильної харчової поведінки та їхньої корекції проводили серед жінок вікової групи 25-35 років (кількість досліджуваних - 10 осіб), у яких виявилося неможливим провести зниження маси тіла (проведення корекції IMT) упродовж двох місяців із використанням одних тільки фрізичних навантажень програми оздоровчого фрітнесу без одночасного проведення корекції харчового статусу та фрактичного харчування.

Для опрацювання отриманих даних було використано вітчизняну інформаційну комп'ютеризовану технологію «Аналіз харчування спортсменів» 3 комп'ютерною програмою «Олімп» [3]. Комп'ютеризована технологія дозволяє оцінювати та корегувати фрактичне харчування на всіх трьох основних рівнях збалансованості харчового раціону - загальному, розширеному та спеціальному та оцінювати хімічний склад харчового раціону за 75 показниками, харчовий статус (у тому числі за таким показником, як (MT) та добові енергетичні витрати організму, ступінь позитивної мотивації до правильної харчової поведінки. Фактичне харчування та ступінь позитивної мотивації до правильної харчової поведінки визначали з використанням анкетно-опитувального методу.
Дослідження проводили на базі Національного транспортного університету та фрітнес-клубу «Аквафріт» (м. Київ, Україна). Кількісні дані обробляли методом математичної статистики «Оцінка достовірності відмінностей двох серій спостережень, проведених на одній і тій же групі випробовуваних» [8].

Результати дослідження та їх обговорення. За допомогою анкетно-опитувального методу та інформаційної комп'ютеризованої технології «Аналіз харчування спортсменів» 3 комп'ютерною програмою «Олімп» було складено та проаналізовано добовий раціон харчування досліджуваних осіб із визначенням вмісту нутрієнтів у добовому харчовому раціоні та енергетичної цінності добового раціону (табл. 1).

Як видно з даних, які наведені в таблиці 1, фактичне харчування обстежуваних жінок віком 25-35 років за енергетичною цінністю відповідає нормам харчування для населення України [9, 10]. За якісним складом нутрієнтів відмічається надмірне споживання білків та жирів тваринного походження, моно-, дисахаридів та недостатнє складних вуглеводів. Надмірне споживання жирів тваринного походження в перспективі може призвести до розвитку атеросклерозу. Такий раціон у жінок 25-35 років викликає розвиток ожиріння під час зниження фрізичних навантажень (припинення занять фрітнесом). Після корекції фактичного раціону - раціон за якісним та кількісним складом відповідав нормативам, які прийняті в Україні [10].

Формування позитивної мотивації до правильної харчової поведінки осіб, які займаються

ТАБЛИЦЯ 1 - Вміст нутрієнтів у добовому харчовому раціоні та його енергетична цінність у жінок віком 2535 років, які займаються аквафітнесом $(M \pm m), n=10$

\begin{tabular}{|l|c|c|c|}
\hline \multirow{2}{*}{\multicolumn{1}{|c|}{ Нутрієнт }} & \multicolumn{2}{|c|}{ Середнє значення } & \multirow{2}{*}{ Норма } \\
\cline { 2 - 3 } & до корекції & $\begin{array}{c}\text { після } \\
\text { корекції }\end{array}$ & \\
\hline Білки, г & & & \\
\hline тваринні & $68 \pm 5$ & $40 \pm 1$ & 40 \\
\hline рослинні & $38 \pm 3$ & $33 \pm 1$ & 32 \\
\hline Усього: & $106 \pm 9$ & $73 \pm 3$ & 72 \\
\hline Жири, г & & & \\
\hline тваринні & $82 \pm 7$ & $49 \pm 1$ & 51 \\
\hline рослинні & $24 \pm 2$ & $22 \pm 1$ & 22 \\
\hline Усього: & $106 \pm 8$ & $71 \pm 2$ & 73 \\
\hline Вуглеводи, г & $76 \pm 4$ & $54 \pm 2$ & 54 \\
\hline $\begin{array}{l}\text { моносахариди та ди- } \\
\text { сахариди }\end{array}$ & & & \\
\hline крохмаль & $114 \pm 6$ & $300 \pm 5$ & 341 \\
\hline Енергетична цінність, ккал & $2689 \pm 120$ & $2454 \pm 42$ & 2500 \\
\hline
\end{tabular}


аквафрітнесом, проводили з використанням соціально-просвітницького тренінгу та рольової гри «Дієтолог» [12]. Після проведення тренінгу ступінь мотивації до здорового харчування статистично достовірно покращився до рівня - достатня (понад 20 балів). Ступінь мотивації до правильної харчової поведінки жінок віком 25-35 років, які займаються аквафрітнесом ( $\mathrm{M} \pm \mathrm{m} ; \mathrm{n}=10$ ), становив: до проведення тренінгу - 15,4 \pm 1,54 бала; після проведення тренінгу - 25,5 $\pm 2,55$ бала; середнє $-10,1 \pm 0,41$ бала; $p<0,001$.

Таким чином, запропонована модель фрормування позитивної мотивації до правильної харчової поведінки осіб, які займаються аквафрітнесом, $\epsilon$ досить ефеективною. Для статистичної обробки результатів було використано критерій різниць, який показав достовірність відмінностей між даними до та після проведення соціально-просвітницького тренінгу.

Для оцінювання харчового статусу жінок віком 25-35 років, які займаються аквафітнесом, було проведено визначення індексу маси тіла (IMT) до та після корекції харчування за допомогою приладу TANITA. IMT визначали за методичними

\section{Література}

1. АкВааэробика и фритнес в Минске. Аквааэробика. [Электронный ресурс] // Режим доступа: http://www. aquafitness.by/akvaaerobika/.

2. АкВафотнес и питание. Миллион меню. [Электронный ресурс] //Режим доступа: http://www. mmenu.com/stati/zdorovoe_pitanie/604/.

3. А. с. 36403 Україна; заявл. 06.01.11. Комп'ютерна програма оцінки та корекції харчування спортсменів «Олімп» / Є. К. Кириленко, С. В. Фус, О.І.Циганенко, Є. О. Лошкарьова, М. Й. Ящур.

4. БаскоВ А. Я. Методология научного исследования / А. Я. Басков, Н. В. Туленков. - К.: МАУП, 2004. - 215 с.

5. Всё об аквафритнесе. - [Электронный ресурс] // Режим доступа: http://www.wellnesshall.ru/vsjo-obakvafitnese.

6. ГориеВа А. Аэробика, фиитнесс, шейпинг / А. Горцева - М.: Физкультура и спорт, 2002. - 123 с.

7. Лоуренс Д. Аквааэробика. Упражнения в воде / Д. Лоуренс. - М.: ФАИР-ПРЕСС, 2000. - 256 с.

8. МамаеВ А. Основы медицинской статистики: учеб. пособие / А. Мамаев - М.: Медицина, 2011. - 128 с.

9. Методичні рекомендації для лікарів загальної практики - сімейної медицини з приводу консультування пацієнтів щодо основних засад здорового харчування / [укл. А. Григоренко] і наказом МОЗ України № 15 від 14.01.2013 р. - К.: МОЗ України, 2013. - 28 с.

10. Про затвердження норм фрізіологічних потреб населення України в основних харчових речовинах та енергії // Наказ МОЗ України № 272 від 18.11.99, чинний від 02.12.1999. - К.: МОЗ України, 1999.

11. Профоит Э. Аквааэробика 120 упражнений / Э. Просрит, П. Лопез. - К.: Феникс, 2007. - 125 с. рекомендаціями [7]. До корекції харчування IMT становив у середньому 29,70 $\pm 2,97$ бала, а після $-27,39 \pm 2,73$ бала; середнє 2,30 \pm 0,56 бала; $\mathrm{p}<0,01$.

Наведені дані свідчать про адекватність корекції харчового раціону, який наведений в таблиці 1.

\section{Висновки}

Оцінка фрактичного харчування жінок 25-35 років, які займаються аквааеробікою, за добовим раціоном показала, що за якісним складом добового раціону відмічається надмірне споживання білків та жирів тваринного походження, моно-, дисахаридів та недостатнє споживання складних вуглеводів за наявності недостатньої мотивації до правильної харчової поведінки.

Проведення соціально-просвітницького тренінгу формування позитивної мотивації до правильної харчової поведінки осіб та корекція добового харчового раціону статистично достовірно привели $(p<0,01)$ до нормалізації IMT жінок віком 25-35 років, які займаються аквафрітнесом.

\section{References}

1. Aqua aerobics and fitness in Minsk. Aqua aerobics. - [Electronic resource] // Access mode: http://www. aquafitness.by/akvaaerobika/.

2. Aqua fitness and nutrition. Million menu. - [Electronic resource] //Access mode: http://www.mmenu.com/stati/ zdorovoe_pitanie/604/.

3. A. s. 36403 Ukraine; appl. 06.01.11. «Olimp» computer program for estimation and correction of athletes' nutrition / E. K. Kyrylenko, S. V. Fus, O. I. Tsyganenko, E. O. Loshkariova, M. Y. Yaschur.

4. Baskov A. Y. Methodology of scientific study / A. Y. Baskov, N. V. Tulenkov. - Kiev: MAUP, 2004. - 215 p.

5. Everything about aqua fitness. - [Electronic resource] // - Access mode: http://www.wellnesshall.ru/vsjo-obakvafitnese.

6. Gortseva A. Aerobics, fitness, shaping / A. Gortseva. - Moscow: Fizkultura i sport, 2002. - 123 p.

7. Lawrence D. Aqua aerobics. Water exercises / D. Lawrence. - Moscow: FAIR-PRESS, 2000. - 256 p.

8. Mamayev A. Bases of mathematical statistics: teaching guide / A. Mamayev - Moscow: Meditsina, 2011. - 128 p.

9. Methodical recommendations for general practitioners with respect to consulting patients in healthy nutrition / [comp. A. Hryhorenko] and order of the Ministry of Public Health of Ukraine N 15 of 14.01.2013. - Kyiv: MPH of Ukraine, 2013. - 28 p.

10. On approval of the norms of physiological requirements of Ukrainian population in basic nutritional substances and energy / Order of the Ministry of Public Health of Ukraine N 272 of 18.11.99, valid since 02.12.1999. - Kyiv: MPH of Ukraine, 1999.

11. Profit E. Aqua aerobics 120 exercises / E. Profit, P. Lopes. - Kiev: Feniks, 2007. - 125 p. 
12. Черниченко I. О. Інформаційний лист про нововведення в сорері охорони здоров'я. Формування позитивної мотивації до правильної харчової поведінки осіб, які займаються фрізичною культурою з використанням соціальнопросвітницького тренінгу / [І. О. Черниченко, Я. В. Першегуба, О. І. Циганенко та ін.]; уст.-розр.: ДУ Ін-т гігієни та мед. екології ім. О. М. Марзєєва НАМН України, НУФВСУ, Укрмедпатентінформ МОЗ України. - К.: МОЗ України. 2013. - № 39. - 2013. - 4 с.

13. Яних Е. А. Аквааэробика / Е. А. Яних. - М.: Физкультура и спорт, 2006. - 189 с.
12. Chernychenko I. O. Information letter about innovations in health care system. Formation of positive motivation to proper nutrition behavior in patients engaged in physical culture with application of socio-educational training / [I. O. Chernychenko, Y. V. Pershehuba, O. I. Tsyhanenko et al.]; ust.-rozr.: DU Institute of Hygiene and Medical Ecology named after O. M. Marzeiev of NAMS of Ukraine, NUPESU, Ukrmedpatentinform MPH of Ukraine. - Kyiv: MPH of Ukraine. - 2013. - N 39. - 2013. -4 p.

13. Yanykh E. A. Aqua aerobics / E. A. Yanykh. Moscow: Fizkultura i sport, 2006. - 189 p. 